\title{
Kinerja Usaha Pembekuan Ikan Kakatua (Scaridae) dengan Metode Air Blast Freezing di PT Prima Pangan Madani Simeulue
}

\author{
[Freezing Business Performance of Cockatoo Fish (Scaridae) Using the Method \\ Air Blast Freezing at PT Prima Pangan Madani Simeulue]
}

\author{
Sisi Melina, lin Siti Djunaidah
}

Program Studi Penyuluhan Perikanan, Politeknik Ahli Usaha Perikanan Jalan Cikaret No 2 Bogor Selatan Kota Bogor 16132

\begin{abstract}
Abstrak
Penelitian ini bertujuan untuk mengetahui sistem produksi dan menganalisis kelayakan usaha pembekuan ikan kakatua (Scaridae) dengan metode Air Blast Freezing di PT Prima Pangan Madani. Penelitian dilaksanakan melalui metode magang di Desa Lugu Kecamatan Simeulue Timur, Kabupaten Simeulue, Provinsi Aceh pada bulan September hingga Oktober 2020. Berdasarkan hasil penelitian dapat disimpulkan bahwa PT Prima Pangan Madani menggunakan sistem produksi pembekuan ikan kakatua yang terdiri dari beberapa tahap yaitu penerimaan bahan baku, penyortiran ikan dan kualitas, penimbangan serta pencatatan, penyusunan dalam pan per ukuran, pembekuan ke dalam ABF selama 13 jam, proses glazing, penimbangan dan pencatatan, pengemasan serta penyimpanan. Rata-rata kapasitas bahan baku usaha pembekuan ikan kakatua sebesar $4000 \mathrm{~kg}$ per bulan. Persentase produksi pembekuan ikan kakatua ukuran A sebesar $40 \%$ dan ukuran B sebesar $60 \%$ dalam 1 (satu) bulan, dengan menggunakan suhu $\mathrm{ABF}$ yang dapat mencapai $-35^{\circ} \mathrm{C}$ hingga $-40^{\circ} \mathrm{C}$. Hasil analisis kelayakan usaha menunjukkan bahwa PT Prima Pangan Madani Simeulue ini layak dijadikan usaha dengan indikator kelayakan usaha yaitu BEP (Harga) Rp. 31.193.595, BEP (Unit) $2.259 \mathrm{~kg}, \mathrm{ROI}=29 \%$, $\mathrm{PP}=1,2$ tahun, $\mathrm{R} / \mathrm{C}=1,29$ dan menghasilkan keuntungan sebesar Rp. 120.000 .000 per bulan.

Kata kunci: air blast freezing; kakatua; kelayakan usaha

\section{Abstract}

This study aims to determine the production system and analyze the feasibility of freezing the parrot Scaridae with the method Air Blast Freezing at PT Prima Pangan Madani. The research was carried out through an apprenticeship method in Lugu Village, East Simeulue District, Simeulue Regency, Aceh Province from September to October 2020. Based on the results of the study it can be concluded that PT Prima Pangan Madani that the parrot freezing production system has several stages, namely receiving raw materials, sorting fish and quality, weighing and recording, stacking in pan per size, freezing into ABF for 13 hours, process glazing, weighing and recording, packaging, storage. In the parrot freezing business, the average raw material capacity is $4000 \mathrm{~kg}$ per month. For the percentage of parrot fish size, A $40 \%$ and size B $60 \%$ in one month of freezing parrot fish production. With $\mathrm{ABF}$ temperatures it can reach $-35^{\circ} \mathrm{C}$ to $-40^{\circ} \mathrm{C}$. The results of the business feasibility analysis show that PT Prima Pangan Madani Simeulue is worthy of being a business with a business feasibility indicator, namely BEP (Price) Rp. 31,193,595, BEP (Unit) $2,259 \mathrm{~kg}, \mathrm{ROI}=29 \%, \mathrm{PP}=1.2$ years, $\mathrm{R} / \mathrm{C}=1.29$ and making a profit of $\mathrm{Rp} .120,000,000$ per month.
\end{abstract}

Keywords: air blast freezing; cockatoo; feasibility

Penulis Korespondensi

Sisi Melina | melinasisi14@gmail.com 


\section{PENDAHULUAN}

Ikan kakatua atau Parrot Fish adalah spesies ikan laut yang cukup digemari masyarakat. Ikan ini memiliki banyak manfaat dan kandungan nutrisi untuk kesehatan, yang terkenal adalah sebagai sumber protein yang rendah lemak. Selain itu, ikan ini juga banyak mengandung omega 3 dan omega 6 yang berfungsi untuk pertumbuhan otak.

Salah satu kelemahan produk perikanan adalah mudah mengalami kemunduran mutu setelah proses penangkapan. Kemunduran mutu ikan yang memengaruhi terjadinya pembusukan terutama disebabkan karena adanya aktivitas enzim, kimiawi, dan bakteri pembusuk (Murniyati dan Sunarman 2000). Untuk mempertahankan mutu ikan dengan baik maka dilakukan pengawetan dan pengolahan ikan yang bertujuan menghambat atau menghentikan mikroorganisme sebagai penyebab pembusukan dan kerusakan pada mutu ikan.

Pembekuan merupakan proses pengolahan, yaitu suhu produk atau bahan pangan diturunkan di bawah titik beku, dan sejumlah air berubah bentuk menjadi kristal es (Estiasih, Ahmadi, dan Kusumastuti, 2009). Menurut Effendi (2009), dengan membekunya sebagian kandungan air bahan atau dengan terbentuknya es sehingga ketersediaan air menurun, maka kegiatan enzim dan jasad renik dapat dihambat atau dihen- tikan sehingga dapat mempertahankan mutu bahan pangan. Metode yang banyak digunakan pada proses pembekuan adalah metode Air Blast Freezing (ABF). Metode pembekuan yang memanfaatkan udara dingin, yaitu dengan menghembuskan dan mengedarkan udara dingin ke sekitar produk secara kontinu (Murniyati dan Sunarman 2000). Menurut Saulina (2009), metode pembekuan ini dilakukan dengan cara menempatkan produk pada rak-rak pembeku di dalam ruang pembekuan, kemudian udara bersuhu rendah dihembuskan ke sekitar produk yang disimpan pada rak-rak pembekuan tersebut.

Kabupaten Simeulue terdiri atas 1 (satu) pulau besar dan 63 (enam puluh tiga) pulau kecil. Perairan lautnya seluas $\pm 9.968,16 \mathrm{~km}^{2}$ yang merupakan bagian dari Samudera Hindia dengan potensi perikanan tangkap yang sangat tinggi. Ini mengakibatkan sebagian besar penduduknya yang berdiam di pesisir dan sangat mengandalkan hasil laut. Pemanfaatan potensi sumber daya perikanan yang tinggi, namun dalam pengelolaan perikanan tangkap berkelanjutan masih belum dilakukan secara optimal. Pabrik pengolahan ikan (cold storage) yang berlokasi di kawasan Lugu, Kecamatan Simeulue Timur, Kabupaten Simeulue yang telah dioperasikan diharapkan dapat meningkatkan ekonomi masyarakat nelayan dan hasil tangkapan yang diper- 
oleh akan diolah di pabrik cold storage Lugu sebelum diekspor ke berbagai luar kota ataupun ke mancanegara. Adapun tujuan dari penelitian ini untuk mengetahui sistem produksi dan menganalisis kelayakan usaha pembekuan ikan kakatua (Scaridae) dengan metode air blast freezing di PT Prima Pangan Madani Simeulue.

\section{BAHAN DAN METODE}

Penelitian dilakukan pada bulan September hingga Oktober 2020. Metode kegiatan yang dilaksanakan dalam penelitian ini adalah metode observer as participant, dengan mengikuti dan mengerjakan proses kegiatan yang dilakukan oleh PT Prima Pangan Madani di Kecamatan Simeulue Timur Kabupaten Simeulue Provinsi Aceh. Metode ini dimaksudkan untuk memperoleh data dan informasi yang bersumber dari hasil wawancara, observasi, diskusi serta mengikuti serangkaian kegiatan produksi didukung oleh sumber referensi yang terkait dengan sistem bisnis perikanan.

Data yang sudah didapatkan dianalisis dan diolah dalam bentuk tabulasi, kemudian dianalisis secara matematis dengan merujuk pada aspek-aspek perhitungan analisis kelayakan finansial, yaitu Break Even Point (BEP), Net Present Value (NPV), Payback Period, Incremental Rate of Return (IRR), dan Rasio B/C (Kusuma 2012).

\section{Analisis Kelayakan Usaha}

Usaha Analisis kelayakan usaha melibatkan beberapa perhitungan biaya, Perhitungan biaya yang dilakukan meliputi biaya investasi, biaya variabel-semi variabel, biaya tetap, dan biaya lainnya. Biaya investasi adalah sejumlah modal atau biaya yang digunakan untuk memulai usaha atau mengembangkan usaha (Pujawan 2004). Biaya variabel merupakan biaya yang rutin dikeluarkan setiap dilakukan usaha produksi dan besarannya tergantung pada jumlah produk yang ingin diproduksi (Ardhana et al. 2008). Adapun pedoman yang digunakan untuk mengetahui status kelayakan usaha adalah:

\section{Revenue-Cost ratio $(R / C)$}

Analisis $\mathrm{R} / \mathrm{C}$ merupakan alat analisis yang digunakan untuk melihat keuntungan relatif suatu usaha dalam 1 (satu) tahun terhadap biaya yang dipakai dalam kegiatan tersebut. Suatu usaha dikatakan layak jika nilai R/C lebih besar dari satu $(R / C>1)$. Semakin tinggi nilai $\mathrm{R} / \mathrm{C}$, maka tingkat keuntungan suatu usaha akan semakin tinggi (Mahyuddin 2010).

$$
\mathrm{R} / \mathrm{C} \text { Ratio }=\frac{\text { Total Pendapatan }}{\text { Total Biaya Produksi }}
$$

\section{Payback Periode (PP)}

Analisis PP bertujuan untuk mengetahui tingkat pengembalian investasi 
yang telah ditanamkan pada suatu usaha (Mahyuddin 2010). Estimasi jangka waktu pengembalian investasi suatu industri dapat ditunjukkan dengan perhitungan Payback Period (Fazwa et al. 2019). $\mathrm{PP}=\frac{\text { Total Investasi }}{\text { Keuntungan }} \times$ Periode Produksi

\section{Break Event Point (BEP)}

BEP merupakan alat analisis yang digunakan untuk mengetahui batas nilai produksi atau volume produksi suatu usaha sehingga mencapai titik impas dalam artian tidak untung dan tidak rugi. Usaha dinyatakan layak apabila nilai BEP produksi lebih besar dari jumlah unit yang sedang diproduksi saat ini, sedangkan nilai BEP harga harus lebih rendah daripada harga yang berlaku saat ini (Mahyuddin 2010).

$$
\begin{aligned}
& \operatorname{BEP}(\mathrm{Rp})=\frac{F C}{1-\left(\frac{V C}{S}\right)} \\
& \operatorname{BEP}(\text { Unit })=\frac{F C}{P-V C}
\end{aligned}
$$

Keterangan:

$\mathrm{FC}=$ Biaya Tetap (Fixed Cost)

$\mathrm{VC}=$ Biaya Variabel (Variable Cost)

$\mathrm{S}=$ Penjualan

$\mathrm{P}=$ Harga jual

\section{Return of Investment (ROI)}

Return of Investment merupakan nilai keuntungan yang diperoleh pengusaha dari setiap jumlah uang yang diinvestasikan dalam periode waktu tertentu. Analisis ROI digunakan untuk mengukur kemampuan dalam mengembalikan modal yang telah dikeluarkan. Pada umumnya, besar kecilnya ROI ditentukan oleh: (a) Kemampuan pengusaha meng hasilkan laba, (b) Kemampuan pengusaha dalam mengembalikan modal, (c) Penggunaan modal dari luar untuk memperbesar perusahaan, sehingga analisis $\mathrm{ROI}$ dapat digunakan untuk mengukur efisiensi penggunaan modal dalam perusahaan tersebut (Susanti, Prayitno, dan Sarjito 2016).

$$
\text { ROI }=\frac{\text { Laba Usaha }}{\text { Modal Usaha }} \times 100 \%
$$

\section{HASIL DAN PEMBAHASAN}

\section{Hasil}

Sub Sistem Pasokan Input

Penyediaan Bahan Baku

Pada prinsipnya pengadaan bahan baku adalah proses mengadakan atau menyediakan bahan baku yang siap diproses. Bahan baku yang digunakan adalah ikan kakatua yang berasal dari pemasok atau nelayan masyarakat $\mathrm{Si}$ meulue. Ada dua jenis ukuran ikan kakatua konsumsi yang dibutuhkan oleh PT Prima Pangan Madani, yaitu ukuran A dengan berat $>500$ gram.ekor $^{-1}$ dan ukuran $B$ dengan berat 300-500 gram.ekor ${ }^{-1}$. Ukuran A dan B memiliki harga beli yang berbeda. Ikan kakatua ukuran A dihargai Rp. $18.000 \mathrm{~kg}^{-1}$ dan untuk ukuran B dihargai Rp. $10.000 \mathrm{~kg}^{-1}$. Pengiriman dilakukan setiap hari sebelum proses produksi dimulai. Jumlah ikan yang dikirimkan dalam sekali pengiriman 
sebesar $200 \mathrm{~kg}$ dan diantarkan langsung oleh pemasok ke PT Prima Pangan Madani. Volume yang dikirimkan disesuaikan dengan volume produksi ikan kakatua.

\section{Modal}

Sumber modal yang digunakan dalam pembekuan ikan kakatua di PT Prima Pangan Madani Simeulue merupakan modal yang dikeluarkan dari kantor pusat PT Prima Pangan Madani yang ada di Jakarta. Modal awal yang digunakan PT Prima Pangan Madani Simeulue sebesar Rp. 1.500.000.000.

\section{Tenaga Kerja}

Pelaksanaan produksi di PT Prima Pangan Madani dilakukan oleh sejumlah 15 karyawan yang terdiri dari 14 orang laki-laki dan 1 orang perempuan yang berusia 20-50 tahun. Karyawan dikelompokkan menjadi 3 golongan pekerja. Penggolongan ini didasarkan pada wewenang kerja dan besaran upah atau gaji yang diterima. Golongan tersebut adalah karyawan bulanan tetap, karyawan tetap, dan karyawan borongan atau karyawan harian. Karyawan bulanan tetap merupakan karyawan yang tetap bekerja meskipun tidak ada proses produksi di dalam pabrik, meliputi administrasi, pemasaran, petugas kebersihan dan sebagainya. Karyawan borongan merupakan pekerja yang biasanya berhubungan langsung dengan proses produksi dan sifatnya tidak tetap karena tergantung dari ketersediaan bahan baku yang akan di produksi. Gaji karyawan diberikan pada tanggal 1 setiap bulannya. Karyawan tetap memperoleh gaji sebesar Rp. 1.500.000 per bulan, karyawan bulanan sebesar Rp.1.000.000 per bulan, dan kompensasi gaji karyawan borongan sebesar Rp.500.000. Gaji merupakan pembayaran atas penyerahan jasa yang dilakukan oleh karyawan yang mempunyai jabatan manajer, umumnya gaji dibayarkan secara tetap per bulan (Mulyadi 2010).

\section{Sub Sistem Proses Produksi}

Proses pembekuan ikan kakatua dijalankan sesuai Prosedur Operasional Standar (POS) yang ada di perusahaan. Proses pembekuan ikan kakatua meliputi

1) Penerimaan bahan baku. Bahan baku berupa ikan kakatua (Scaridae) dibeli dari pemasok atau nelayan Simeulue. Perusahaan hanya akan membeli ikan apabila menggunakan es dan untuk penerimaan ikan dari nelayan dimulai pukul 09.00 WIB hingga 17.00 WIB. Setelah tiba di perusahaan, bahan baku diseleksi dan ditimbang. Menurut Suryanto dan Daryanto (2018), kualitas dan kuantitas bahan baku yang digunakan untuk produksi mempunyai andil yang besar karena dapat menentukan produk yang dihasilkan. 
Bahan baku yang digunakan didapatkan dari beberapa sektor diantaranya menyediakan sendiri (self made), pembelian dari pemasok (pemasok), dan bekerjasama dengan usaha lain (cooperation);

2) Seleksi ukuran dan kualitas. Bahan baku diseleksi atau disortir sesuai dengan ukuran yang telah ditentukan oleh PT Prima Pangan Madani. Ikan kakatua yang diterima Perusahaan adalah ikan kakatua ukuran konsumsi. Ada dua jenis ukuran ikan kakatua konsumsi yang menjadi bahan baku PT Prima Pangan Madani, yaitu ukuran A dengan berat $>500$ gram. ekor $^{-1}$ dan ukuran $B$ dengan berat 300-500 gram.ekor ${ }^{-1}$. Ikan tersebut juga disortir sesuai standar penerimaan bahan baku di perusahaan, seperti ikan tidak boleh tertembak di badan, tidak ada tambahan garam dan bahan pengawet, mata cerah, insang segar, dan aroma ikan tidak busuk. Hal ini sesuai dengan pernyataan Dewan Standarisasi Nasional Indonesia (2006) bahwa bahan baku harus bersih, bebas dari setiap bau yang menandakan pembusukan, bebas dari tanda-tanda dekomposisi dan pemalsuan, bebas dari sifat-sifat alamiah lain yang dapat menurunkan mutu serta tidak membahayakan kesehatan
3) Penimbangan dan pencatatan. Setelah ikan disortir, ikan dibersihkan atau dicuci dengan air bersih. Kemudian ikan ditimbang dan dipisahkan sesuai dengan ukurannya, lalu dilakukan pencatatan.

4) Penyusunan ke dalam pan. Setelah ikan ditimbang, ikan disusun rapi ke dalam pan sesuai ukuran ikan dan diberi kode untuk mempermudah mengetahui ukuran ikan tersebut.

5) Pembekuan ke dalam ABF. Ikan di dalam pan dimasukkan ke dalam ABF dan disusun rapi. Pembekuan ikan dilakukan selama 13 jam dengan suhu $-35^{\circ} \mathrm{C}$ hingga $-40^{\circ} \mathrm{C}$;

6) Proses glazing, penimbangan, dan pencatatan. Setelah dibekukan, ikan dikeluarkan dari ABF. Proses selanjutnya adalah glazing menggunakan viber yang didalamnya terdapat air es. Ikan yang telah beku dicelupkan ke dalam viber selama dua sampai tiga menit. Hal tersebut dilakukan untuk menambah berat ikan meminimalkan perubahan kandungan air pada saat pengiriman.

\section{Sub Sistem Pasca Produksi Pengemasan}

Setelah proses glazing, ikan ditimbang dan diberi label. Produk dikemas menggunakan karung goni khusus yang berisi ikan kakatua bermuatan $30 \mathrm{~kg}$ dan kemudian diikat. 
Tabel 1 Analisis Usaha Pembekuan Ikan

\begin{tabular}{|c|c|c|}
\hline No & Analisis Usaha & Nilai \\
\hline \multirow[t]{3}{*}{1.} & Biaya Investasi & \\
\hline & a) 3 produk $(\mathrm{Rp})$ & 1.218 .775 .000 \\
\hline & b) 1 produk (Rp) & 406.258 .333 \\
\hline \multirow[t]{3}{*}{2.} & Biaya Penyusutan & \\
\hline & a) 3 produk $(\mathrm{Rp})$ & 13.346 .290 \\
\hline & b) 1 produk (Rp) & 4.448 .763 \\
\hline 3. & Biaya Tetap (Rp.bulan $\left.{ }^{-1}\right)$ & 35.248 .763 \\
\hline 4. & Biaya Variabel (Rp.bulan $\left.{ }^{-1}\right)$ & 57.760 .000 \\
\hline 5. & Harga Modal $\left(\mathrm{Rp}_{\mathrm{kg}} \mathrm{k}^{-1}\right)$ & 23.252 \\
\hline 6. & Biaya Produksi (Rp.bulan-1) & 93.008 .763 \\
\hline 7. & Produksi (kg.bulan-1) & 4000 \\
\hline 8. & Harga $\left(\right.$ Rp.kg $\left.^{-1}\right)$ & 30.000 \\
\hline 9. & Pendapatan (Rp.bulan-1) & 120.000 .000 \\
\hline 10. & Keuntungan (Rp.bulan-1) & 26.991 .237 \\
\hline 11. & $\mathrm{R} / \mathrm{C}$ & 1,29 \\
\hline 12. & PP & 1,2 \\
\hline 13. & BEP (Rp.) & 31.193 .595 \\
\hline 14. & $\mathrm{BEP}(\mathrm{kg})$ & 2.259 \\
\hline 15. & ROI (\%) & 29 \\
\hline
\end{tabular}

\section{Penyimpanan}

Setelah ikan kakatua dikemas, ikan tersebut akan disimpan ke dalam cold storage. Sebelum ikan masuk ke dalam cold storage, ikan didata terlebih dahulu di buku pencatatan barang masuk yang terdiri dari jenis ikan, ukuran, berat ikan (kg) dan jumlah karung. Setelah itu ikan dimasukkan ke dalam cold storage. Suhu di dalam Cold storage adalah $-18^{\circ} \mathrm{C}$ hingga $-23^{\circ} \mathrm{C}$.

\section{Sub Sistem Pemasaran}

Kegiatan pemasaran yang dilakukan oleh PT Prima Pangan Madani Simeulue adalah saluran pemasaran langsung. PT Prima Pangan Madani Simeulue mengirimkan 5 ton ikan dalam satu kali pengiriman ke PT Prima Pangan Madani Jakarta. Setibanya di Jakarta, ikan akan dipasarkan ke rumah makan, restoran di dalam dan luar negeri. Ikan dikirimkan menggunakan mobil boks dari Simeulue ke kantor pusat PT Prima Pangan Madani Jakarta. Untuk pembelian secara online, ikan juga dikirim melalui 
mobil boks sesuai dengan tujuan tempat pemesanan. PT Prima Pangan Madani Jakarta juga memasarkan produknya ke luar kota seperti yang ada di Banten, Jawa Barat ,Jawa Timur, Jawa Tengah. Harga satu kilo ikan kakatua di tingkat distributor adalah Rp. $30.000 \mathrm{~kg}^{-1}$.

\section{Sub Sistem Layanan Pendukung}

Kegiatan yang dilaksanakan oleh

PT Prima Pangan Madani Simeulue sangat didukung oleh pemerintah setempat. Pemerintah setempat melalui Dinas Kelautan dan memberikan 2 mobil boks besar untuk mempermudah proses pemasaran ikan kakatua. PLN sebagai salah satu layanan pendukung lainnya juga memasok energi listrik setiap harinya untuk PT Prima Pangan Madani, untuk mendukung operasional sebagian besar mesin dan alat-alat yang ada di perusahaan tersebut.

\section{Analisis Usaha}

Data hasil analisis usaha dapat dilihat pada Tabel 1.

\section{Pembahasan}

\section{Penyediaan Bahan Baku}

Permasalahan yang sering terjadi disebabkan oleh kurangnya ketersediaan bahan baku saat musim hujan atau terang bulan. Pada waktu tersebut nelayan tidak melaut atau kesulitan mendapatkan ikan sehingga menghambat proses pro- duksi pembekuan ikan kakatua. Menurut Riyadi (2012), ketersediaan bahan baku dalam sebuah industri merupakan hal yang sangat penting, sebab bahan baku merupakan salah satu faktor yang menjamin kelancaran proses produksi. Persediaan bahan baku dimaksudkan untuk memenuhi kebutuhan bahan baku dalam suatu proses produksi dimasa yang akan datang.

\section{Modal}

Abbas (2018) menyatakan bahwa sumber modal usaha dapat diperoleh dari modal sendiri, bantuan pemerintah, dan lembaga keuangan baik bank maupun lembaga keuangan bukan bank. Modal adalah faktor usaha yang harus tersedia sebelum melakukan kegiatan. Modal yang digunakan pada seluruh proses produksi menggunakan modal pribadi, dikarenakan Direktur PT Prima Pangan Madani tidak ingin memiliki banyak hutang melalui pinjaman modal dari bank dalam menjalankan usahanya. Lebih lanjut Hossain dan Ali (2012) menyatakan bahwa perusahaan tidak akan mencapai nilai optimal jika semua permodalan berasal dari hutang, sehingga untuk itu direktur perusahaan harus secara cermat dan tepat dalam mengelola komposisi modal perusahaan (Hossain dan Ali 2012). 


\section{Tenaga Kerja}

Tenaga kerja direkrut dari penduduk di sekitar wilayah pabrik. Hal ini bertujuan untuk melibatkan warga sekitar dan memudahkan mobilitas pekerja. Mekanisme rekrutmen hanya sebatas pada pembicaraan dari mulut ke mulut. Perusahaan mendapatkan rekomendasi caIon tenaga kerja dari tenaga kerja yang telah bekerja untuk selanjutnya dilakukan proses seleksi tenaga kerja. Setelah diterima, karyawan akan melalui masa percobaan selama beberapa waktu. Hal ini sejalan dengan Nuraeni (2013) yang menyatakan bahwa terdapat beberapa dasar pertimbangan dalam penetapan tugas kepada karyawan meliputi keahlian, pengalaman, pendidikan, usia, jenis kelamin serta keadaan fisik dari setiap karyawan.

\section{Pengemasan dan Penyimpanan}

Label adalah bagian dari barang yang berupa keterangan mengenai produk tersebut seperti jenis ikan, tanggal produksi, ukuran ikan, dan berat ikan. Keterangan ini berfungsi untuk mempermudah karyawan pada saat melakukan pemasaran. Menurut Laksana (2008) fungsi dari label yaitu untuk menjelaskan beberapa hal mengenai produk meliputi siapa yang membuat, di mana dibuat, kapan dibuat, bagaimana harus digunakan dan lain-lain. Tujuan dari pengemasan ini untuk mempermudah proses peng- angkutan. Setelah dikemas, ikan kemudian disimpan dalam suhu dingin. Hal ini dilakukan untuk mempertahankan kesegaran mutu ikan sampai proses pemasaran dilakukan.

\section{Sub Sistem Pemasaran}

Harga dari suatu produk ditentukan oleh besarnya pengorbanan yang dilakukan dan laba yang diharapkan. Perubahan harga jual kepada konsumen ini tergantung pada jarak tempat berjualan dengan tempat produksi. Semakin jauh tempat pemasaran dari tempat produksi, maka harga jual ke konsumen juga semakin tinggi. Hal ini disebabkan karena biaya pengangkutan yang semakin besar.

\section{Analisis Usaha}

Menurut Rahardi, Nazaruddin, dan Kristiawati (2008) analisis usaha dalam bidang perikanan merupakan pemeriksaan keuangan untuk mengetahui keberhasilan yang telah dicapai selama usaha perikanan itu berlangsung. Dengan analisis usaha ini, pengusaha membuat perhitungan dan menentukan tindakan untuk memperbaiki dan meningkatkan keuntungan dalam usaha mereka.

Suatu usaha dikatakan layak apabila nilai $R / C$ ratio lebih besar dari satu $(\mathrm{R} / \mathrm{C}>1)$. Semakin tinggi nilai $R / C$ ratio, maka tingkat keuntungan suatu usaha akan semakin tinggi (Mahyuddin 2010). 
Usaha pembekuan ikan kakatua yang dilakukan oleh PT Prima Pangan Madani Simeuleu memiliki $\mathrm{R} / \mathrm{C}$ rasio sebesar $1,29 \%$. Artinya bahwa setiap penambahan biaya sebesar Rp.1000, akan ada tambahan penerimaan Rp. 1.290 , sehingga usaha layak untuk dilanjutkan. Investasi yang telah dikeluarkan oleh PT Prima Pangan Madani untuk pembekuan ikan kakatua ini akan kembali apabila memproduksi produk ikan kakatua selama 1,2 tahun (1 tahun 2 bulan 12 hari).

PT Prima Pangan Madani akan mengalami titik impas apabila mampu menghasilkan produk sebanyak $2.259 \mathrm{~kg}$ atau menghasilkan penjualan produk ikan kakatua senilai $R p$ 31.193.595. Apabila penjualan belum mencapai nilai tersebut maka usaha tersebut akan mengalami kerugian. Nilai Return of Investment $(\mathrm{ROI})$ yang diperoleh pada produksi ikan kakatua adalah sebesar $29 \%$, artinya dalam satu bulan produksi produk ikan kakatua mampu mengembalikan $29 \%$ dari biaya produksi yang telah dikeluarkan.

\section{SIMPULAN}

Adapun simpulan hasil penelitian yang berlokasi di PT Prima Pangan Madani Simeulue ini adalah :

1. PT Prima Pangan Madani Simeulue melakukan usaha pembekuan ikan kakatua dengan menggunakan metode Air Blast Freezing. Tahapan pro- ses produksi ikan kakatua meliputi penerimaan bahan baku, penyortiran ikan dan kualitas, penimbangan dan pencatatan, penyusunan dalam pan, pembekuan ke dalam $A B F$, proses glazing, penimbangan dan pencatatan, pengemasan serta penyimpanan. Kapasitas produksi rata-rata PT Prima Pangan Madani Simeulue sebesar $4000 \mathrm{~kg}$ ikan per bulan dengan harga jual Rp. 30.000 per kg, sehingga dalam kurun waktu 1 (satu) bulan dapat menghasilkan pendapatan sebesar Rp. 120.000.000.

2. Analisis kelayakan usaha membuktikan bahwa usaha pembekuan ikan kakatua di PT Prima Pangan Madani Simeulue adalah sebuah usaha pengolahan yang layak untuk dijalankan. Hal tersebut dapat dilihat dari nilai $R / C$ sebesar1,29. Nilai $R / C$ yang lebih dari satu artinya usaha tersebut layak untuk dilanjutkan. Titik impas dari penjualan ikan kakatua BEP (Rp) Rp. 31.193.595, BEP (unit) 2.259 kg ikan kakatua, dan ROI sebesar 29\%.

\section{PERSANTUNAN}

Terima kasih disampaikan kepada Kepala Unit Praktik Lapang Komunikasi dan Penyuluhan, Politeknik Ahli Usaha Perikanan dan PT Prima Pangan Madani atas izin dan dukungan fasilitas dalam mendukung pelaksanaan penelitian. 


\section{DAFTAR PUSTAKA}

Abbas, Djamila. 2018. "Pengaruh Modal Usaha, Orientasi Pasar, Dan Orientasi Kewirausahaan Terhadap Kinerja Ukm Kota Makassar." Jurnal Minds: Manajemen Ide dan Inspirasi 5(1):95-111. doi:

10.24252/minds.v5i1.4991.

Ardhana, I. Ketut, Bambang Pramudya, Maharani Hasanah, dan Armansyah H. Tambunan. 2008 . "Pengembangan tanaman jarak pagar (Jatropha Curcas L) mendukung kawasan mandiri energi di Nusa Penida, Bali." Jurnal Littri 14(4). doi: http://dx.doi.org/10.21082/littri.v14n 4.2008.\%25p.

Effendi, Supli. 2009. Teknologi Pengolahan dan Pengawetan Pangan. Bandung (ID): Alfabeta.

Estiasih, Teti, Kgs Ahmadi, dan Fitriyah Kusumastuti. 2009. "Optimasi kondisi pemurnian asam lemak omega-3 dari minyak hasil samping penepungan tuna (Thunnus Sp.) dengan kristalisasi urea." Jurnal Teknologi dan Industri Pangan 20(2):135.

Fazwa, M. A. Farah, P. Ahmad Fauzi, A. G. Ab Rasip, dan M. Mohd Noor. 2019. A preliminary analysis on financial assessment of Citrus hystrix (limau purut) grown on plantation basis.
Hossain, Faruk, dan Ayub Ali. 2012. "Impact of firm specific factors on capital structure decision: an empirical study of Bangladeshi Companies." International Journal of Business Research and Management 3(4):163-82.

Kusuma, Parama Tirta Wulandari Wening. 2012. "Analisis Kelayakan Finansial Pengembangan Usaha Kecil Menengah (UKM) Nata De Coco di Sumedang, Jawa Barat." AJIE 1(2):113-20.

Laksana, Fajar. 2008. Agribisnis Perikanan. Jakarta (ID): Penebar Swadaya.

Mahyuddin, Kholis. 2010. Panduan Lengkap Agribisnis Lele. Jakarta (ID): Penebar Swadaya.

Mulyadi. 2010. Akuntansi Biaya Edisi 5. Yogyakarta (ID): Universitas Gadjah Mada.

Murniyati, A. S., dan Dan Sunarman. 2000. Pendinginan, Pembekuan, dan Pengawetan Ikan. Yogyakarta (ID): Kanisius.

Nuraeni, Hani. 2013. Manajemen Sumber Daya Manusia. Bandung (ID): Politeknik LPKIA.

Pujawan, I. Nyoman. 2004. Ekonomi Teknik. Surabaya (ID): Penerbit Guna Widya.

Rahardi, Floribertus, Nazaruddin, dan Regina Kristiawati. 2008. Agribisnis 
Perikanan. Jakarta (ID): Penebar Swadaya.

Riyadi, Aziz Slamet. 2012. "Analisis Efisiensi Persediaan Bahan Baku Industri Abon Lele Karmina di Kabupaten Boyolali [Skripsi]." Universitas Sebelas Maret.

Saulina, Hernita. 2009. "Pengendalian Mutu Pada Proses Pembekuan Udang Menggunakan Statistical Process Control (SPC) di PT. Lola Mina [Skripsi]." Institut Pertanian Bogor.
Suryanto, Bambang, dan Daryanto. 2018. Manajemen Bisnis Usaha Kecil. TSmart. Tangerrang (ID).

Susanti, Slamet Budi Prayitno, dan Sarjito. 2016. "Penggunaan Ekstrak Daun Bakau (Rhizophora apiculata) untuk Pengobatan Kepiting Bakau (Scylla serrate) yang Diinfeksi Bakteri Vibrio harveyi terhadap Kelulushidupan." Journal of Aquaculture Management and Technology 5(2):18-25. 